\title{
The Normal Insulin Response to Glucose
}

\section{The Relationship between Blood Sugar and Plasma Insulin}

\author{
K.D. Buchanan and M.T. MoKIDdie
}

The Diabetic Clinic, Royal Infirmary, Glasgow

Received November 2, 1966

\begin{abstract}
Summary. Plasma insulin values during a 50 g. oral glucose tolerance test were measured by immuno-assay in 34 control subjects. Peak insulin levels occurred within the first 60 minutes and the fasting level was approached by 120 minutes. The insulin curve elosely resembled the blood sugar curve and a significant correlation was found between the blood sugar and plasma insulin values at 60,90 and 120 minutes after oral glucose. The results suggest that the wide range in plasma insulin response is due in part at least to variations in the blood sugar. The results also tend to confirm that immuno-reactive insulin. is biologically significant.
\end{abstract}

La réponse normale de l'insuline au glucose. Relation entre la glycémie et l'insuline plasmatique.

Résumé. On a mesuré les valeurs de l'insuline plasmatique, à l'aide du dosage immunologique, pendant un test de tolérance à $50 \mathrm{~g}$ de glucose administré par voie orale, chez 34 sujets témoins. Les taux maximums d'in. suline se situaient dans les 60 premières minutes, et à 120 minutes les taux étaient proches de ceux à jeun. La courbe de l'insuline ressemblait étroitement à la courbe de la glycémie et on a trouvé une relation significative entre les valeurs de la glycémie et de l'insuline plasma. tique, 60,90 et 120 minutes après l'administration orale de glucose. Les résultats suggèrent que la large bande de variations dans la réponse de l'insuline plasmatique est due, au moins en partie, aux variations de la glycémie. Les résultats tendent également à confirmer que l'insuline immunoréactive est biologiquement significative.

Die normale Insulinausschüttung nach Glukosegaben. Die Beziehung zwischen Blutzucker und Plasma-Insulin.

Zusammenfassung. Die Plasma-Insulinwerte während der oralen Glukosebelastung mit $50 \mathrm{~g}$ Glukose wurden bei 34 Normalpersonen immunologisch gemessen. Die Höchstwerte wurden innerhalb der ersten 60 Minuten erreicht, nach 120 Minuten näherten sich die Spiegel wieder dem Nüchternwert. - Die Insulinkurve ähnelte der Blutzuckerkurve stark. Wir fanden eine signifikante Korrelation zwischen Blutzucker- und Plasmainsulinwerten 60,90 und 120 Minuten nach der oralen Glukosezufuhr. Die Ergebnisse deuten darauf hin, daß die starken Unterschiede in der Insulinausschüttung zum Teil durch Schwankungen der Blutzuckerwerte bedingt sind. Sie stiutzen ferner die Anschauung, daß das immunologisch nachweisbare Insulin biologische Bedeutung hat.

Key-words: Normal Plasma Insulin Response; Glucose Tolerance, Relationship, Blood Sugar, Immunoassay.

\section{Introduction}

It has been reported that the plasma insulin response to oral glucose in normal, non-obese individuals, as measured by immuno-assay, shows a wide range (WELBORN et al., 1966; Berson and YaLOW, 1965). WELBORN et al. (1966) studied normal subjects who were not overweight, and were unable to relate this wide insulin response to age, sex, percentage ideal weight, fat fold thickness or family history of diabetes but they did find a tendency for high insulin secretors to have higher blood sugars than low insulin secretors. RUEDI et al. (1963) found that in normal subjects the insulin curves had the same form as the glucose curves during oral glucose tolerance tests. SAmols and Marks (1965a) and Garcia et al. (1966) showed an excellent correlation between the blood sugar and serum insulin during intravenous glucose tolerance tests.

The present paper deals with the normal plasma insulin response to oral glucose and the relationship between the blood sugar and the plasma insulin.

\section{Methods and materials}

Normal subjects. The group consisted of $\mathbf{3 4}$ healthy volunteers with a negative family history of diabetes.
None was more than $14 \%$ overweight (Life Extension Institute of New York), and all had normal glucose tolerance, in that their blood sugars did not exceed $110 \mathrm{mg} / 100 \mathrm{ml}$ fasting, $180 \mathrm{mg} / 100 \mathrm{ml}$ at 30 minutes, and $120 \mathrm{mg} / 100 \mathrm{ml}$ at 120 minutes, during the glucose tolerance test.

The 34 subjects comprised 20 males and 14 females, aged $15-65$ years (mean 34 years), and weight range $84-114 \%$ (mean $99 \%$ ) of ideal body weight.

Test procedure. All subjects were instructed to eat a normal diet for at least 3 days prior to the test. A standard $50 \mathrm{~g}$ oral glucose tolerance test was performed, bloods being taken fasting and at 30, 60, 90, and 120 , and in some cases 15 minutes after the oral glucose. Plasma insulin was assayed according to the immuno-precipitation technique of HALES and RANDLE (1963a). Standards and antisera used, and the accuracy of the assay are as described elsewhere (BUCHANAN and McKIDDIE, 1967).

Blood sugars were estimated as total reducing substances using a modification of the HagedornJensen technique on the autoanalyser.

WELBoRN et al., (1966) have shown that normal plasma insulin values have a skew distribution and our results supported this. Conversion of the plasma 
insulin values to their respective logarithms produced a more symmetrical distribution for statistical analysis by Student's ' $t$ ' test. When the means and standard deviations so derived are re-converted to their respective logarithms two values for standard deviation are obtained because of the skew distribution.

\section{Results}

The Insulin response after $50 \mathrm{~g}$ oral glucose. The insulin rise after $50 \mathrm{~g}$ oral glucose is shown in Fig. 1. The insulin levels at each time were found to be distributed in a log. normal fashion. The mean insulin levels \pm 1 standard deviation, in $\mu$ units $/ \mathrm{ml}$, were fasting, $20_{-13}^{+34} ; 15$ minutes, $70_{-27}^{+41} ; 30$ minutes, $85_{-38}^{+74}$; 60 minutes, $74_{-45}^{+67} ; 90$ minutes, $37_{-20}^{+46}$; and 120 minutes, $19_{-11}^{+23}$. The mean insulin rise over the fasting level in the first hour was $72_{-34}^{+110} \mu$ units $/ \mathrm{ml}$. All subjects had their peak insulin response in the first hour, and in every subject there was a fall in plasma insulin at 90 minutes, and by 120 minutes the plasma insulin had approached the fasting level.

INSULIN RESPONSE IN 34 CONTROL SUBJECTS. MEANS \pm IS.D.

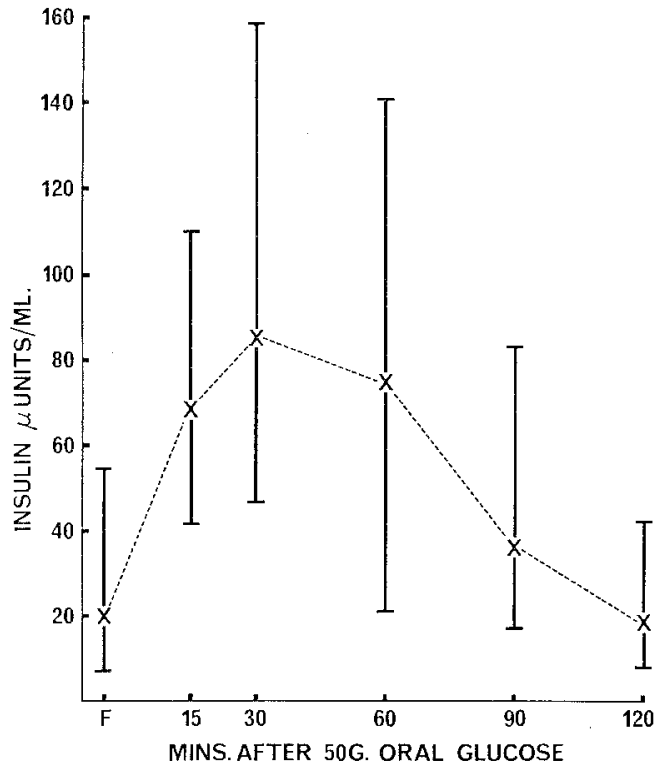

Fig. 1. Plasma insulin response after $50 \mathrm{~g}$ oral glucose in 34 control subjects. Means \pm Standard Deviation calculated from logarithmic distribution (see text).

The relationship of the plasma insulin to the blood sugar. The blood sugars in $\mathrm{mg} / 100 \mathrm{ml}$ (mean \pm 1 standard deviation) in the 34 control subjects during the $50 \mathrm{~g}$ oral GTT, were found to be: fasting, $91 \pm 10$; 15 minutes, $122 \pm 41 ; 30$ minutes, $129 \pm 26 ; 60$ minutes, $101 \pm 29,90$ minutes $82 \pm 21$ and 120 minutes $74 \pm$ 13. The relationship of the plasma insulin and sugar response is shown in Fig. 2. Both curves appear similar. Correlation coefficients between the plasma insulin and blood sugar were calculated for each time. There was no significant correlation fasting and at 15 and 30 minutes, but there were significant positive correlations at 60,90 and 120 minutes: $-r=+0.59$ (p. $<0.001) ; r=+0.35(p<0.05)$; and $r=+0.35$ $(p<0.05)$ respectively.

\section{BLOOD SUGAR AND PLASMA INSULIN RESPONSE} IN 34 CONTROL SUBJECTS

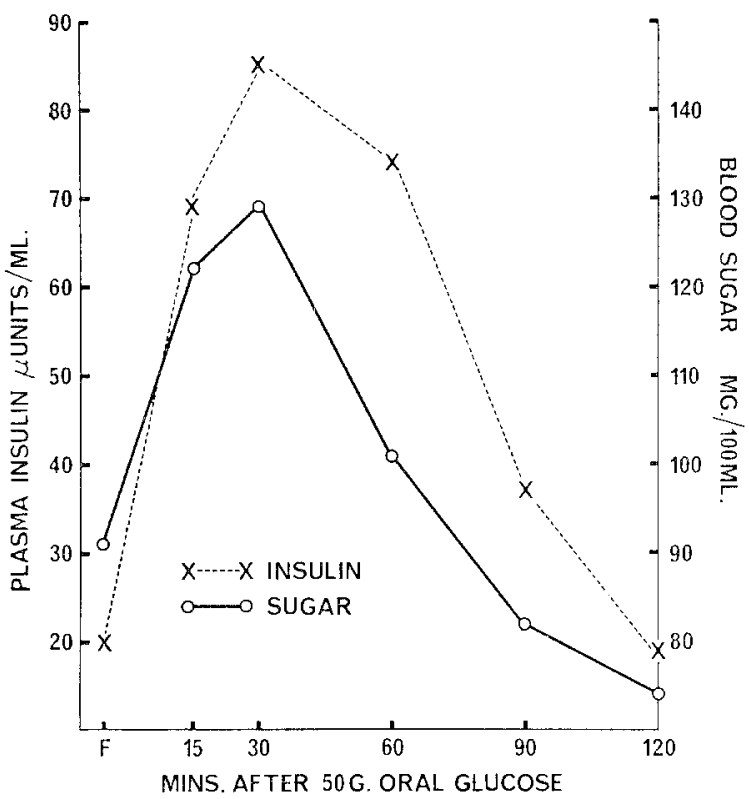

Fig. 2. The mean blood sugar and plasma insulin curves following $50 \mathrm{~g}$ oral glucose in 34 control subjects.

The relationship of the timing of the insulin response to the blood sugar. The subjects were divided into 3 groups according to the timing of their insulin response.

A. 'Early' insulin responders (5 subjects): plasma insulin at 30 minutes greater than $20 \mu$ units over the fasting level, but within $20 \mu$ units of the fasting value at 60 minutes.

B. 'Intermediate' insulin responders (14 subjects): plasma insulin still elevated at 60 minutes but within $20 \mu$ units of fasting level at 90 minutes.

C. 'Late' insulin responders (12 subjects): plasma insulin still elevated at 90 minutes but within $20 \mu$ units of the fasting level at 120 minutes.

The mean insulin and sugar responses of these 3 groups are shown in Fig. 3. The sugar curves followed the insulin response very closely. There was no significant difference between the blood sugar levels up to 30 minutes, but at 60 minutes the intermediate and late insulin responders showed significantly higher blood sugars than the early insulin responders $(p<$ 0.01 and $p<0.001$ respectively), and the late insulin responders also showed a significantly higher blood sugar than the intermediate insulin responders $(p<$ $0.01)$. At 90 minutes there was no significant difference between the blood sugars of the early and intermediate 
insulin responders, but the late insulin responders showed a significantly greater blood sugar than both the early and intermediate responders $(p<0.01$ and $p<0.01$ respectively).

\section{TIMING OF INSULIN AND SUGAR RESPONSE.}

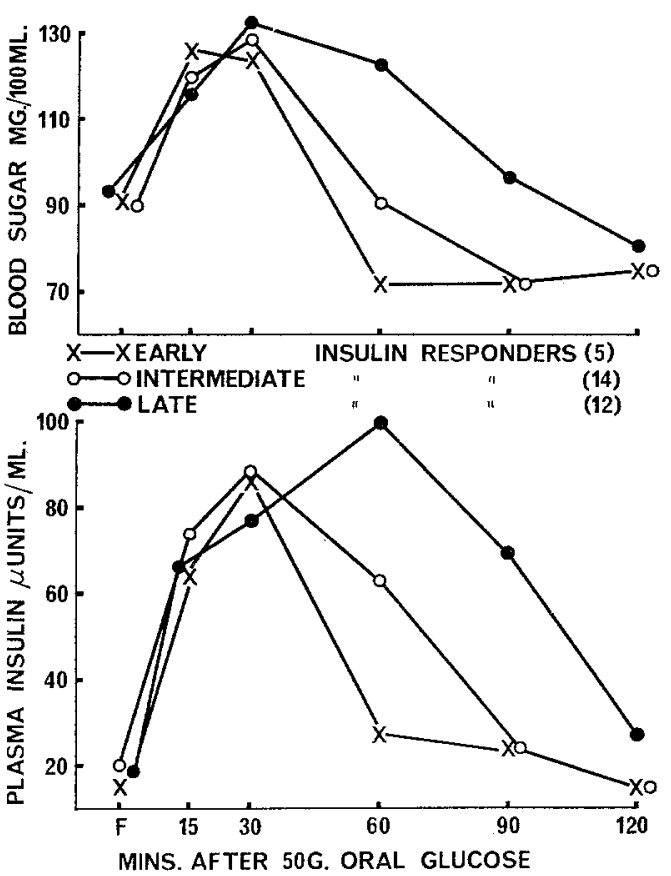

Fig. 3. The relationship between the blood sugar and plasma insulin levels in the early, intermediate, and late insulin responders (for definitions see Text).

\section{INSULIN AND SUGAR RESPONSE.}

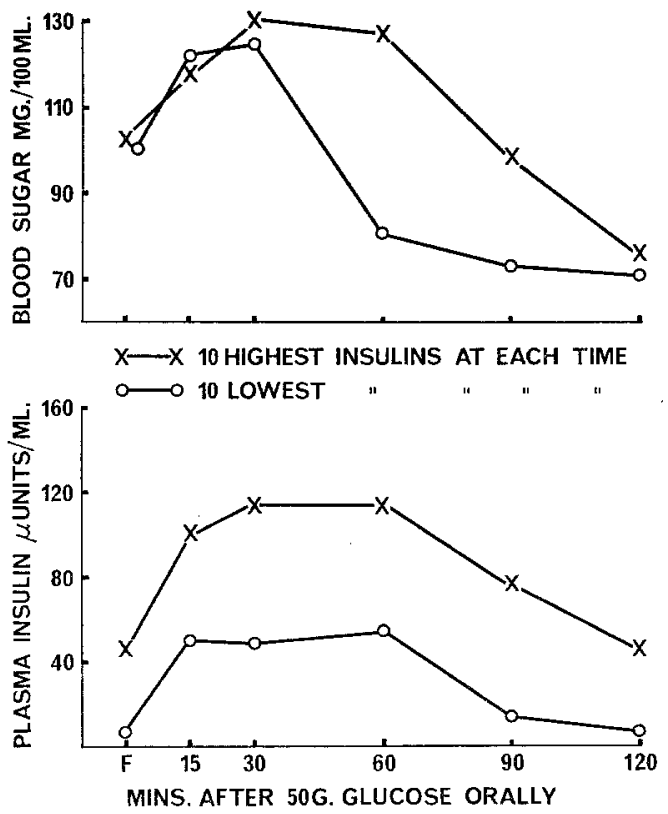

Fig. 4. The blood sugars of the patients with the 10 highest insulin levels are compared with those of the 10 lowest insulin levels.
The relationship of the degree of insulin response to the blood sugar. The mean of the 10 highest plasma insulin values at each time interval was compared with the mean of the 10 lowest. The blood sugar values related to these 10 highest and 10 lowest plasma insulins were also compared. (Fig. 4). At 60 and 90 minutes the blood sugar values corresponding to the 10 highest insulin levels were significantly higher than those corresponding to the 10 lowest levels. However the fasting blood sugar values and those at 15, 30 and 120 minutes were very similar for the two groups.

\section{Discussion}

The normal plasma insulin levels reported by different workers show considerable variations (Table 1). Some of these studies were only on small groups of

Table 1. The normal fasting insulin levels reported by various workers using immuno-assay

\begin{tabular}{|c|c|c|c|c|}
\hline \multicolumn{2}{|l|}{ Author } & Mean & $\begin{array}{l}\text { Range (R) } \\
1 \text { Standard } \\
\text { Deviation (SD) } \\
\text { or Standard error } \\
\text { of mean (S.E.M.) }\end{array}$ & $\begin{array}{l}\text { No. of } \\
\text { Subjects }\end{array}$ \\
\hline \multicolumn{2}{|c|}{ BERSON and YALOW (1962) } & 21 & $0-68(\mathbf{R})$ & 30 \\
\hline CERASI and LUFT & $(1963)$ & 46 & $36-52(\mathrm{R})$ & 6 \\
\hline HALES and RANDLE & (1963) & 16 & $6-25(\mathrm{R})$ & 5 \\
\hline ELRTCK et al. & $(1964)$ & 60 & \pm 10 (S.D.) & $\begin{array}{l}\text { not } \\
\text { stated }\end{array}$ \\
\hline NrkKILA et al. & $(1965)$ & 8 & \pm 8 & 11 \\
\hline Metant et al. & $(1965)$ & 22 & \pm 10 (S.D.) & 30 \\
\hline \multicolumn{2}{|c|}{ SOELDNER and SLONE (1965) } & 8.5 & $\begin{array}{l} \pm .5 \\
\text { (S.E.M.) }\end{array}$ & 75 \\
\hline KaRAM et al. & $(1966)$ & $\overline{-}$ & $10-19(\mathrm{R})$ & 8 \\
\hline SHFt DON et al. & (1966) & 22 & $\pm 7(\mathrm{SD})$ & 22 \\
\hline Sussman et al. & $(1966)$ & 24 & $\pm 15(\mathrm{SD})$ & 20 \\
\hline WELBORN et al. & $(1966)$ & 9 & $\begin{array}{l}+6(\mathrm{SD}) \\
+\quad 4\end{array}$ & 45 \\
\hline SELTZER et al. & $(1967)$ & 11 & - 1 (S.E.M.) & 21 \\
\hline BUCHANAN and McK & IDDIE & 20 & $\begin{array}{l}+34 \\
-13\end{array}$ & 34 \\
\hline
\end{tabular}

subjects e.g. HaLes and RANDle (1963), and KaRam etal. (1966), and the difference may have occurred by chance. The differences between other groups of results may reflect variations in method of assay and the lack of a universal insulin standard. Samols and Brukus (1964), from a study of the different immunoassay procedures, concluded that variation in results in their hands depended only on the variety of standards used. However the difference between our fasting result $\left(20_{-13}^{+34}\right)$ and that of WELBORN et al. $(1966), 9_{-1}^{+6}$ cannot be explained on the standard insulin or insulin antisera used, as they were identical. Difficulties giving rise to variable results occur in the double antibody insulin assay (Somldner and Slone, 1965). Cross reaction of the anti-gamma globulin serum with human gamma globulin may give rise to spuriously high results (Wrubors et al., 1965), which can be prevented by purifying the anti-gamma globulin (WELBORN and Fraser, 1965) or reduced by pre-precipitating the anti-insulin serum (HaLes and RaNDLE, 1963). An 
inhibitor of the two antibody immunoassay method has been reported by Morgar etal. (1964a), and this inhibiter may give falsely high values. The inhibitor has been identified as complement (MoRgan et al., 1964b; Welborn and Fraser, 1965), and can be overcome by heparin (WELBORN and FraSeR, 1965) or EDTA (Sheldon and TAYLor, 1965). In the assay reported here since EDTA was present in the system and pre-precipitation was practised, the above difficulties should have been minimised.

Because of the different doses of oral glucose used in tolerance tests in various centres, it is difficult to compare the plasma insulin levels after glucose. The majority of American workers use the $100 \mathrm{~g}$ glucose dose, whereas many British workers use the $50 \mathrm{~g}$ glucose tolerance test. It is likely that the greater the dose of glucose, the greater will be the blood sugar rise (WEST et al. 1964) and consequently the greater the rise in plasma insulin levels. HALES and RANDLE (1963) showed higher plasma insulin levels in a group of subjects receiving $100 \mathrm{~g}$ oral glucose, than in a group receiving 50 g glucose.

WELBORN et al., (1966) report a fairly large group of normal insulin levels after $50 \mathrm{~g}$ glucose. Our results are similar to theirs in timing and distribution, but our mean values at each time are about twice as great as theirs.

It has long been known that glucose stimulates the secretion of insulin directly (ANDERSON and LONG, 1947, FIELd, 1964). We have shown that the insulin response closely follows the blood sugar. However statistical correlation between blood sugar and plasma insulin could only be found at 60,90 and 120 minutes, but not fasting, or at 15 and 30 minutes.

During the first 30 minutes after oral glucose, there is continuing absorption of the glucose from the gut and thus blood sugar and plasma insulin levels may not be closely correlated. However by 60 minutes, most of the glucose having been absorbed, the blood sugar level will more accurately represent insulin action and peripheral and hepatic uptake of glucose. During the intravenous GTT, the glucose is administered rapidly so that correlation between blood sugar and plasma insulin may be expected throughout the test. (Samols and Marks, 1965a; Garcia et al., 1966). The lack of correlation between fasting blood sugar and fasting plasma insulin cannot be explained on this basis. The stimulatory glucose threshold in the pancreas for the release of insulin may vary from individual to individual.

Other factors which must be taken into consideration during the interpretation of the oral glucose tolerance test, are humoral factors released during the absorption of glucose which may stimulate insulin release (McInTYRE et al., 1964). SAMoLs et al., (1965b) suggest that glucagon may be released by oral glucose, and glucagon is now known to stimulate insulin secretion (SAMOLS et al., 1965c; CrockFord et al., 1966; Turner and MoIntyre, 1966). Pfeiffer et al. (1965) and DuPRE et al. (1966) have shown that secretin also increases insulin secretion. More recently UNGER et al. (1967) have shown that pancreozymin, gastrin and secretin all stimulate insulin secretion, and that pancreozymin is also a potent stimulator of glucagon secretion. The insulin secretion after oral glucose may be related to some or all of these hormonal factors, thus providing an alternative explanation for the lack of correlation between blood sugar and plasma in the first 30 minutes after the glucose. However, the correlation between plasma insulin and blood sugar at 60, 90 and 120 minutes does emphasize that the blood sugar is an important stimulus for insulin release.

There is some doubt (YALOW and Berson, 1965) as to whether immuno-reactive insulin is biologically significant. Because of the correlation we have found between the blood sugar and plasma insulin responses, it seems probable that immunological insulin has biological activity.

Acknowledgements. We are grateful to Dr. A.H. IMRIE and Professor E.M. MoGrre for help and encouragement in the preparation of this paper. We thank the biochemistry department for the blood sugar estimations.

\section{Peferences}

Anowrson, E., and J.A. Long: The effect of hypoglycaemia on insulin secretion as determined with the isolated rat pancreas in a perfusion apparatus. Endocrinology 40, 92-97 (1947).

Berson, S.A., and R.S. YALOW: Immunoassay of plasma insulin in Immunoassay of hormones. Ciba Foundation Colloquia on endocrinology. Vol. 14. London, Churchill, pp. $182-200,1962$.

- - Some current controversies in diabetes research. Diabetes 14, 549-572 (1965).

BUCHANAN, K.D., and M.T. McKIDDIE: Experience with the immunoprecipitation technique of insulin assay with reference to sensitivity, precision and specificity. Clin. chim. Acta 15, 315-320 (1967).

Cerasi, E., and R. LUFT: Plasma insulin response to sustained hyperglycaemia induced by glucose infusion in human subjects. Lancet 1963 II, $1359-1361$.

Crockford, P.M., D. Porte, F.C. Wood and R.H. WiLliams: Effect of glucagon on serum insulin, plasma glucose and free fatty acids in man. Metabolism 15, $114-122(1966)$.

Dupré, J., L. RoJas, J.J. WhITE, R.H. UNGER and J.C. BECK: Effects of secretin on insulin and glucagon in portal and peripheral blood in man. Lancet 1966 II, $26-27$.

Elrick, H., L. Strmmuer, C.J. Hlad and Y. AraI: Plasma insulin response to oral and intravenous glucose administration. J. clin. Endocr. 24, 1076-1082 (1964).

Field, J.B.: Factors concerned with insulin synthesis and release. Metabolism, 13, 407-421 (1965).

Garcia, M.J., J.S. Soeldner, R.E. Gleason and R.F. Williams: Proceedings of the 58th Annual Meeting of the American Society for Clinical Investigation. Atlantic City, May 1966.

HAIES, C.N., and P.J. RANDLE : Immunoassay of insulin with insulin antibody precipitate. Biochem. J. 88 , $137-146(1963 \mathrm{a})$.

- Effects of low carbohydrate diet and diabetes mellitus on plasma concentrations of glucose, nonesterified fatty acids and insulin during oral glucose tolerance tests. Lancet 1963 b I, 790-794. 
Karam, J.H., G.M. Grodsky and P.H. Forsham: The relationship of obesity and growth hormone to serum insulin levels. Ann. N.Y. Acad. Sci. Vol. 131 pp. 374387 (1966).

MeInTYRe, N., C.D. Holdoworth and D.S. Turner: New interpretation of oral glucose tolerance. Lancet 1964 II, $20-21$.

Merant, F., H. Drtschuntet, K. M. Barteit, H. FriedRICH and E.F. PfeIfrems: Úber die radioimmunologische Bestimmung von Insulin un Blut. Klin. Wschr. 43, $1000-1007$ (1965).

Morgan, C.R., R.L. Sorensen and A. Lazarow: Studies of an inhibitor of the two antibody immunoassay system. Diabetes 13, $1-5$ (1964a).

- - - Further Studies of an inhibitor of the two antibody immunoassay system. Diabetes 13, 579-584 (1964b).

Nikkild, E.A., T.A. Mretininin, M.R. Vmsense and R. Pelkonen: Plasma insulin in Coronary Heart Disease. Lancet 1965 II, 508-511.

Pfeiffer, von E.F., M. Telib, J. Ammon, F. Melant and H. Ditsoruneit: Direkte Stimulierung der InsulinSekretion in vitro durch Sekretin. Dtsch. med. Wschr. 90, 1667-1668 (1965).

Ruedi, Par B., J.P. Feliber, A. Ersold and A. VaxNorrx: Insulin et activite insulino-semblade. Journal Suisse de Medicine 93, $1004 \cdots 1007$ (1963).

Samols, E., and D. BזrKus: A comparison of insulin immunoassays. Proc. Soc. exp. Med. 115, $79-84$ (1964).

-, and V. MARKs: Interpretation of the intravenous glucose test. Lancet 1965 a I, $462-463$.

- J. Tyler, G. MARRI and V. MARKs: Stimulation of glucagon secretion by oral glucose. Lancet $1965 \mathrm{~b} \mathbf{I I}$, $1257-1259$.

- G. Marri and V. Marks: Promotion of insulin seoretion by glucagon. Lancet $1965 \mathrm{e}$ I, $415-416$.

Seltzer, H.S., E.W. Allen, A.L. Herron and M.T. BrennaN: Relation of Delayed Insulin Release to Car- bohydrate Intolerance in mild Diabetes Mellitus. J. clin. Invest. 46, $323-335$ (1967).

SHELDON, J., and K.W. TAYIOR: The immunoassay of insulin in human serum treated with EDTA. J. Endocr. 33, $157-158$ (1965).

- - and J. ANDERson: The effects of Long-Term Acetohexamide treatment on pancreatic Islet cell function in Maturity-Onset Diabetes. Metabolism 15, $874-883(1966)$.

SomLDNER, J.S., and D. SLONE: Critical variables in the Radioimmunoassay of serum insulin using the double antibody technic. Diabetes 14, $771-779$ (1965).

Sussman, K.E., L. Stimmerer and H. Birenborm: Plasma insulin levels during reactive hypoglycaemia. Diabetes 15, $1-4(1966)$.

TURNer, D.S., and N. McIntyre: Stimulation by glucagon of insulin release from rabbit pancreas in vitro. Lancet $1966 \mathrm{I}, 351-352$.

UNGER, R.H., H. KeTterer, J. DuprÉ and A. M. EtseNTRAUT: The effects of secretin, pancreozymin and gastrin on insulin and glucagon secretion in anaesthetized dogs. J. clin. Invest. 46, 630-645 (1967).

Werborn,T.A., and T.R. Fraser: The Double Antibody Immunoassay of Insulin. A standardised second anti. body reaction that eliminates spurious results with human serum. Diabetologia 1, 211-218 (1965).

- A.H. Rubenstein, R. Hastam and R. Fraser: Normal insulin response to glucose. Lancet $1966 \mathrm{I}, 280-$ 283.

West, K.M., J.A. WulfF, D.G. Reigat and D.T. FitzGerald : Oral carbohydrate tolerance tests. Arch. intern. Med. 113, 641-648 (1964).

Dr. M.T. MoKidDII

The Diabetic Clinic

Royal Infirmary

Glasgow C 4, England 